\title{
Research on Universities Second-hand books Market Based on Financial Accounting Perspective
}

\author{
Luoyifan $\mathrm{Li}^{1}$ \\ ${ }^{1}$ North China Electric Power University, Beijing, China, 102206 \\ hunter2011@foxmail.com
}

Keywords: Used Book Market in University; Financial; Feasibility and Innovative Dupont Analysis

\begin{abstract}
In this paper, North China Electric Power University is taken as an case, we conduct used book market in University of Beijing outlook survey analysis. Nowadays, the whole society firmly adhere to sustainable development, sustainable use of resources as the best way for us to make full use of resources. With the increased demand for college students' textbooks, supplementary books, used book market has also ushered in development opportunities. Many Beijing colleges and universities are also in rising demand for books. At the same time, the emergence of a second-hand book market also has great opportunities. CPI data shows that in recent years, with the rise of society price, the price of the book also has a larger increase. More and more students do not want to choose expensive book, but turned to inexpensive second-hand book market. From the point of view of Financial accounting standard of used book market Beijing colleges and universities, as well as by means of DuPont analysis of the project team, this paper analyzes the feasibility of providing advice for the development of second-hand book market.
\end{abstract}

\section{Introduction}

North China Electric Power University has full-time undergraduates 20,000 people, leaving 20 courses per person, then the North China Electric Power University undergraduate annual consumption of about 600,000 books. Yet it does not include information related to counseling, other research review books and some part-time study books. Assuming an average price of about 25 yuan per book, then the book needs only North China Electric Power University, it reached 15 million. From this, the University of the book market there is a huge market demand. According to the survey, over half of the purchase of new books as disposable resources, after reading one or two abandoned. This caused a great waste of resources and waste of funds, some waste is not treated discarded books also caused severe environmental pollution.

\section{Universities Used Books of Circulation}

In order to better meet the needs of students, we used books for universities circulation methods were investigated. Used book market in University existing circulation has a direct way more common to high school seniors sister school books in the campus bookstore to buy second-hand bookstores and other online purchase.

Purchase books directly from high school seniors sister school. Directly to high school seniors sister school books advantages that only sister school seniors in the school bulletin board notices affixed selling books, leave their contact details, will be able to quickly sell books. This way you can make yourself bookseller earn extra money, but also allows those who buy books cheap books. But the disadvantage of this approach is that transactions of senior high school senior sister apprentice some books most of the basic course of the book, there will be difficult for those who buy books Specialized books, in this way, although convenient, but limited the scope of trading books, can not fully meet books' needs and prone to unfair trade.

In the school campus bookstore to buy books used books. Bookstore books is relatively complete, students need to meet the various professional books, in addition to books students can choose according to their own requirements, such as notes or examinations focused more so on, but most school books bookstore collection of waste paper will price to acquire books. Such low prices will 
make students more willing to sell books directly to mentees, and the schools do not have special used book bookstore, nor related disinfected after being acquired second-hand books.

In the second-hand bookstore to buy books online to sister school seniors in the school's second-hand bookshop and buy

The case is less than the books, students will generally consider the purchase of second-hand bookstore online. Used books online bookstore has been broader, more partial than general scope involving second-hand bookshop of the school's courses can be in used books online bookstore scouring, and can compare prices online used bookstore to choose the most expensive purchase.

\section{Currently Used Book Market in University Problems}

Currently, the used book market is not mature enough universities, there are many shortcomings, our colleges and universities deficiencies second-hand book market were analyzed to look forward to the second-hand book market in University build a more perfect.

The propaganda used book market is not enough. In schools, the propaganda used book market is relatively weak, many students have not had knowledge and understanding of a system of second-hand books, not easily buy. In the school there is no specific time and place to sell used books, did not make the students form buy used books consciousness, the school did not provide any relevant information about the second-hand book market solutions so that students in the secondary market.

The second-hand book market book source dispersion and less second-hand book market failure types of books, professional books mainly small, basic course books more, and in the second-hand book market, it's hard to put all the books need to buy the whole entire book source more dispersed. No second-hand bookshop in the school for students in graduate school on the occasion of the book can only be sold to scrap buyers, second-hand bookstores can not get these books, resulting in insufficient source book, lead to shortages.

Books second-hand book market information lag some books for revision has not taken any measures to update the school textbooks, bookstores will not sell old books cause the phenomenon stockpile. Books update rate is accelerating in, resulting in increased presence of older books used book number, which is second-hand book market is a serious problem. If the book information has been lagging behind, then the student will be on the second-hand book market have a negative impression on the future development of second-hand book market is unfavorable.

\section{Feasibility Analysis in Construction of Second-Hand Book Market Colleges}

Universities Used Book Market Demand Analysis. According to most students think we can accept the existence of the investigation of University second-hand book market, and are willing to accept or use second-hand books, in the use of materials as long as the inside of a useful knowledge on their own will buy. Visible in greater demand in the secondary market, customer or potential demand for second-hand products is relatively large. With a low-carbon economy initiative, not just recycling used books and low-carbon economy advocates thought is consistent, but also to a great extent to meet the needs of most students. Therefore, the establishment of a second-hand bookshop featured is necessary and meaningful things.

Construction of Second-Hand Book Market Advantages of Universities. To learn more about the second-hand book market and universities, we have the advantage of second-hand book market in University conducted a detailed analysis to be able to build a second-hand book market in University of buyers and sellers meet to prepare.

(1) Stable consumer environment advantage. Universities used bookstores major consumer groups are students, students use books, major groups consumed. Huge consumer groups and the number is still relatively stable. In terms of the acquisition of second-hand book sources have the advantage. Through investigation and analysis, the graduates upon graduation, most people still choose the materials, PubMed, Grading and some supplementary information through various 
channels to dispose of, mainly selling scrap, gifts to others or sell second-hand bookshop. Meanwhile, many students said that if you can buy inexpensive books are still very willing to buy.

(2) The price advantage. Universities costly new materials, the price of second-hand books generally relatively low, affordable prices. Especially for the basic course books, generally use a longer time, not revision in the short term, so the purchase of second-hand book is a very affordable choice, low price for the purposes of attractive college students with no income.

(3) Compared with the advantage of the shop. Compared with the online used bookstore, in physical bookstore students can be more convenient, more intuitive to see the books, easy to view the contents of a book, the newness, cleanliness, whether there notes, you can directly choose their satisfaction with the books according to their needs.

\section{Dupont Analysis Based on an Analysis of 100 Back House Projects}

DuPont Financial Analysis is a use of the intrinsic link between several key financial ratios to a comprehensive analysis of the financial position, business performance evaluation of a classical approach from a financial point of view. The basic idea is to business owners return on equity gradual decomposition product of a number of financial ratios, which can be more comprehensive, systematic, intuitively reflect the financial position and operating results of an enterprise, thereby learned sales margin, return on total assets debt ratio, cost structure and asset structure and other aspects of corporate financial information, so that the operators in business objectives occurred when movement can be amended promptly to identify the cause and, at the same time to provide a basis for investors, creditors and government evaluation of enterprises. When analyzed using the DuPont comprehensive financial analysis, we can draw the relationship between the financial indicators into DuPont analysis chart, as shown below:

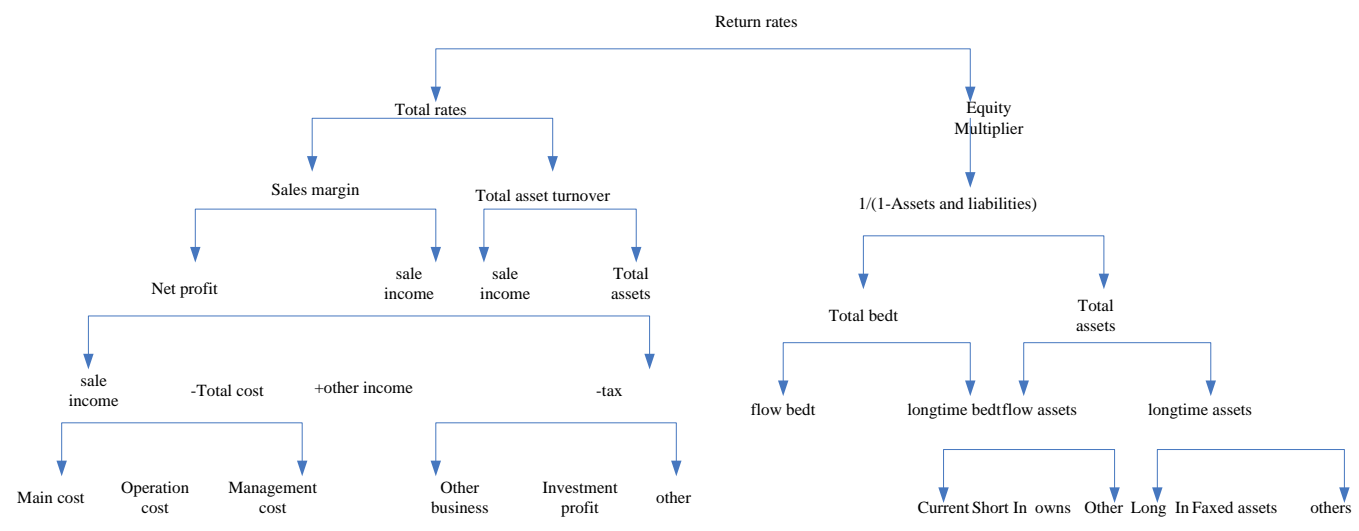

Return on owner's equity $=$ net profit $\div$ average owner's equity $=$ (Net profit $\div$ average total assets $) \times$ (average total assets $\div$ average owner's equity) $=$ return on total assets ratio $\times$ equity multiplier

ROA $=$ net income $\div$ average total assets $=($ Net profit $\div$ sales $) \times($ sales $\div$ average total assets $)=$ net profit margin $\times$ total sales turnover

Equity Multiplier $=$ owner's equity $\div$ total assets $=1 \div$ (owner's equity $/$ total assets $)=1 \div[1$ (liabilities / assets) $]=1 \div(1$ - asset-liability ratio)

Net profit $=$ net profit $\div$ Sales revenue

Total asset turnover $=$ sales $\div$ average total assets

Namely: the return on equity ratio $=$ sales margin equity multiplier $\times \times$ total asset turnover

Average total assets $=($ total assets at the beginning + ending total assets $) \div 2$

The average total liabilities $=($ total debt + beginning Ending total liabilities $) \div 2$

Average Equity $=$ (opening equity + closing in owners' equity $) \div 2$

DuPont Financial Analysis System, the owner of return on equity and corporate profitability, asset turnover, the liabilities, the cost structure and the structure of current assets and long-term assets and other indicators is closely linked to these factors together constitute an interdependent system. Only the relationship between the various elements within the system arrangements, and 
coordinate in order to make the maximum return on equity, shareholder wealth maximization to achieve financial goals. In the specific application should seize the following main aspects:

Return on equity is a most comprehensive method, the most representative of the financial analysis is the core of DuPont Financial Analysis System. Factors that determine the level of return on equity has three aspects: sales margin, total asset turnover and equity multiplier. Sales margin, total asset turnover and equity multiplier of three indicators were reflected in corporate profitability ratios, asset turnover situation and the debt ratio, through analysis of these three indexes can be combined measure of return on equity occurred lifting specific reasons for the change, to facilitate the operator amending them.

The sales margin is the ratio of business net income and sales, its level can sensitively reflect the business management level. The main factors affecting the sales margin is sales revenue and costs, therefore, there are two main ways to improve the sales margin: First, to expand sales, the second is to reduce costs and expenses. The so-called "cut." Increase sales revenue is significant, it first will help improve sales margin, but it is also necessary to improve the conditions and means of the total turnover. While reducing costs and expenses is another important factor to improve sales margin, the use of DuPont financial analysis can study the cost structure of the enterprise is reasonable, in order to provide a basis for seeking ways to reduce costs and expenses.

The total asset turnover ratio is a reflection of enterprises to use assets to achieve sales revenue index capabilities. In general, current assets directly reflects the enterprise's solvency and liquidity; non-current assets reflects the scale and development potential of the enterprise. There should be a rational structure between the ratio of cash if the company holds more than business needs, which may affect the profitability of the enterprise; if companies take up too much inventory and accounts receivable, it is necessary to affect profit capability, but also affect solvency. To this end, it is necessary to further analyze the amount of the turnover rate of occupancy of the assets. Current assets should focus on the analysis of whether there is backlog of inventory, whether monetary idle funds, analysis of accounts receivable in the customer's ability to pay and the availability of possible bad debts; for non-current assets analysis should focus on whether fixed assets are fully utilized.

The equity multiplier indicates the degree of corporate debt is total assets to equity ratio. The index reflects the degree of enterprises to use financial leverage conduct business activities. High debt ratio, equity multiplier is large, indicating a high degree of corporate debt, will have more leverage benefits, but the risk is high; the other hand, a low debt ratio, equity multiplier is small, indicating that the low corporate level debt, will have less leverage benefits, but the risk borne by the respective low. By analyzing the equity multiplier, it can determine whether it is appropriate to raise the proportion of corporate debt, adjust unreasonable financing structure and improve the return on equity.

DuPont can take advantage of the financial analysis of the enterprise cost of basic structure is close. Management fees and the impact on the profit analysis identify a way to reduce costs. Diameter, strengthen cost control. If the company's financial expenses are too high, we must further divided. How Its debt ratio is too high; if the management costs are too high, it is necessary to further analyze its funding. Production can turn around circumstance. DuPont Financial Analysis of interest expense analysis more seriously because Lee. Interest expense and equity multiplier there is a close relationship. If interest expense is high, you should test. Consider corporate equity multiplier or gearing ratio is reasonable, that is, whether the capital structure

Reasonable, if unreasonable, it will affect the interests of the owners.

The use of DuPont financial analysis method can also structural conditions Enterprise Liquid Assets and long-term assets is reasonable analysis. In general, current assets directly reflect the enterprise's solvency and liquidity, and long-term assets are reflected in business scale, the development potential, there is a reasonable ratio between them. If excessive corporate liquidity assets, fixed assets, or excessive, will affect the turnover rate of corporate assets, thus affecting the effect of asset utilization. Similarly, current assets have a reasonable proportion of internal problems. If monetary funds business for more than business needs, it will affect corporate 
profitability; if enterprises occupy too much inventory and accounts receivable, you both will affect profitability, would affect the solvency, then you production and marketing enterprises to analyze whether there is the wrong way, or production of the product cycle is too long, to analyze whether the existence of the phenomenon is not timely collection and further identify the causes and take corrective action responses.

With the DuPont analysis, we can operate on the financial aspects of the project to do the appropriate analysis. After the operation of the project together, can in order to determine the operation of the project, and make the appropriate adjustments. In various research ready early, we found that second-hand book market prospects, and currently there is no specific Huadian used bookstores, we can take full advantage of the resources used books, the operation of the project.

\section{References}

[1] WangLi X. Based on B/S Mode of Online Books Sales, System Analysis and Design. Computer And Modernization: 2007,06: 118 122.

[2] Wu Xi. Management and Development of The Book Market Xue Peng Beijing. Beijing Union University: 2002,12: 53 to 56.

[3] Gu Yuan. Used book market in University. Science and Technology Innovation Herald: 2009,24: 239: 101-104. 